\title{
UJI PERFORMANSI BUOY PLUTO UNTUK PERINGATAN DINI PENCEMARAN PERAIRAN
}

\author{
PERFORMANCE OF PLUTO BUOY FOR \\ WATER POLLUTION EARLY WARNING
}

\author{
Handy Chandra, Daud S. A. Sianturi dan Yustisia Firdaus \\ Pusat Pengkajian dan Perekayasaan Teknologi Kelautan dan Perikanan, Balitbang KP \\ Jl. Pasir Putih 1, Ancol Timur, Jakarta14430 \\ E-mail: handavin@gmail.com
}

Diterima tanggal: 25 September 2014, diterima setelah perbaikan: 21 Nopember 2014, disetujui tanggal: 28 Nopember 2014

\begin{abstract}
ABSTRAK
Aplikasi buoy (pelampung) untuk berbagai keperluan di Indonesia sudah bukan hal yang baru. Ada yang dipergunakan untuk navigasi, pemantauan tsunami, penelitian, perikanan dan energi. Kementerian Kelautan dan Perikanan (KKP) telah mengembangan buoy PLUTO (singkatan Perairan selaLU termoniTOr) tahun 2010. Awalnya buoy PLUTO ini dipergunakan untuk memantau kualitas perairan budidaya rumput laut di Wakatobi dengan sistem non-telemetri. Tahun 2013 dikembangkan kapasitasnya memiliki sistem telemetri. Hasilnya diujikan untuk peringatan dini pencemaran di perairan pelabuhan perikanan Pekalongan. Hasilnya menunjukkan hal positif bahwa dengan memakai 3 sensor saja, yaitu suhu, salinitas dan oksigen terlarut (DO), pencemaran yang terjadi dapat terdeteksi. Demikian pula sistem telemetri berjalan dengan baik.
\end{abstract}

Kata kunci: buoy PLUTO, salinitas, suhu, oksigen terlarut (DO), telemetri.

\section{ABSTRACT}

The utilization of buoy for many applications in Indonesia is something in common. There are usages for navigation, tsunami monitoring, research, fisheries, and energies.The Ministry of Marine Affairs and Fisheries (MMAF) had developed buoy PLUTO (stands for, Perairan selaLU termoniTOr (waters always be monitored)) in 2010. The initial buoy PLUTO was developed to monitor sea grass water monitoring in Wakatobi, without telemetry ability.In 2013 it was equipped with telemetry sistem. The result was testef for pollution early warning in waters of Pekalongan fishing port. The testing showed that by using three sensors, i.e. temperature, salinity, and dissolved oxygen, pollution can be detected. The telemetry system also worked well.

Keywords: buoy PLUTO, salinity, temperature, Dissolved Oxygen (DO), telemetry.

\section{PENDAHULUAN}

Pelampung (buoy) sudah menjadi alat penting dalam dunia maritim, perikanan, energi dan ada banyak jenisnya (Mullen \& Whelan, 2013; Pandoe \& Djamaluddin, 2009; Gates et al., 1996; Howe, 2014; Holappa, 2001; Detrick et al., 2000). Dimulai sebagai fungsi tambatan kapal, buoy kemudian berkembang menjadi alat bantu navigasi (penunjuk alur pelayaran). Selanjutnya, dijadikan alat untuk kompartemen penelitian kelautan karena biaya kapal dan resiko melaut dapat ditekan (Holappa, 2001). Sampai saat ini, begitu banyak variasi pemanfaatan buoy di berbagai sektor. Pemanfaatan buoy untuk bidang energi telah diaplikasikan di Inggris, US, dan Taiwan dengan memakai buoy NOMAD (Howe, 2014). Buoy ini dipakai untuk menghitung potensi angin dalam 1 tahun (24/7) di lepas pantai dan danau, serta sudah dimanfaatkan selama 50 tahun (Howe, 2014).

Aplikasi buoy untuk berbagai keperluan bukan hal baru di Indonesia. Untuk peringatan dini tsunami di Indonesia sudah dimulai sejak 1997, dengan nama Sea Watch buoy (Pandoe \& Djamaluddin, 2009). Selain itu, ada bantuan dari Jerman bernama 
GITEWS buoy sejumlah 8 buah dan selesai dideploy April 2010, Amerika membantu dengan DART buoy, Norwegia melalui pemerintah Malaysia memberikan Wave Scan Tsunameter buoy (Gambar 1 - 4).

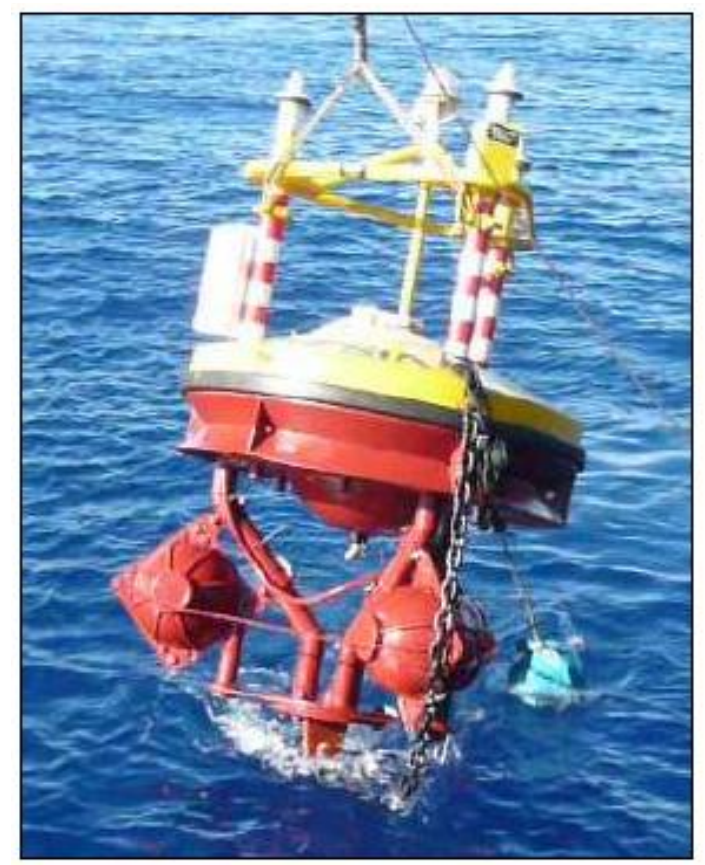

Gambar 1. Sea Watch buoy

Figure 1. Sea Watch buoy

Sumber: Pandoe \& Djamaluddin, 2009

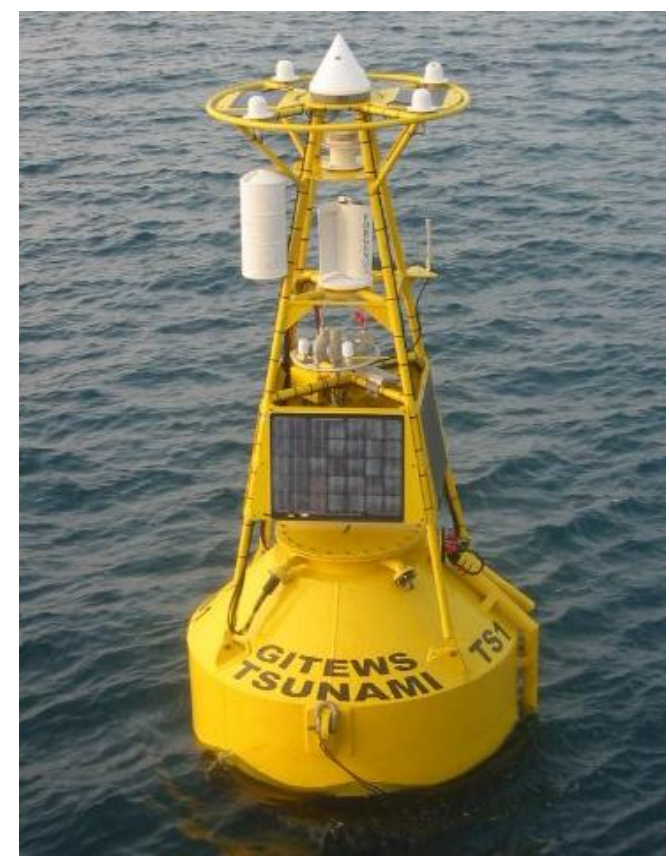

Gambar 2. GITEWS buoy

Figure 1. GITEWS buoy

Sumber: http://www.spiegel.de

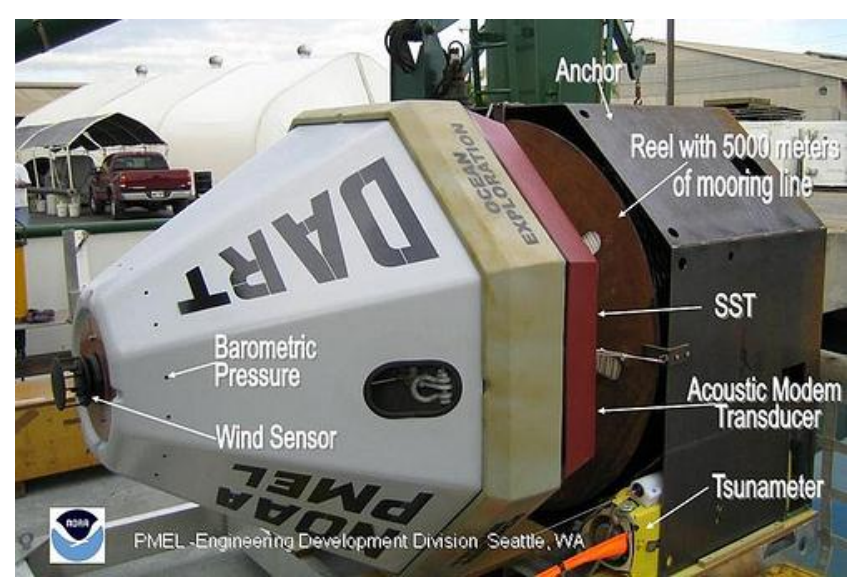

Gambar 3. DART buoy

Figure 3. DART buoy

Sumber: https://www.flickr.com/photos

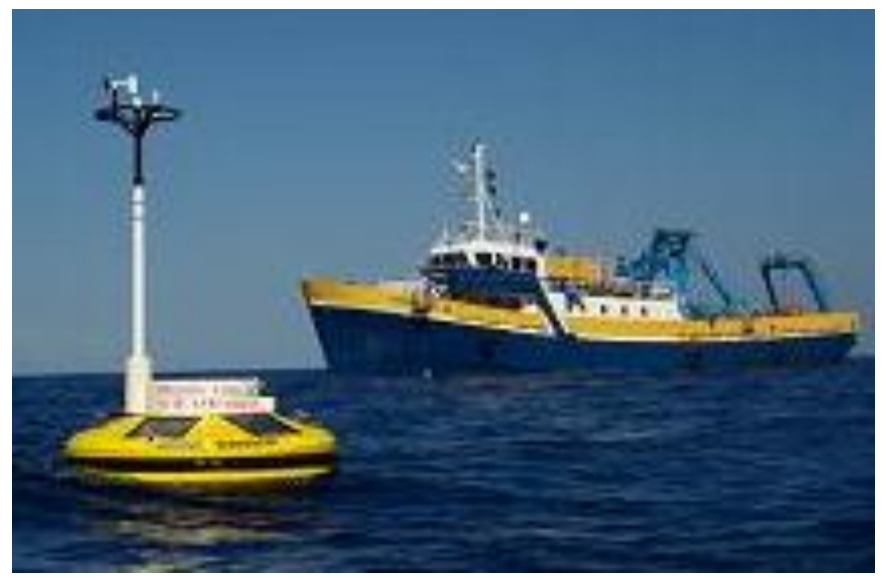

Gambar 4. Wave Scan Tsunameter buoy Figure 4. Wave Scan Tsunameter buoy Sumber: http://www.oceanor.info

Untuk pemantauan perairan laut di Indonesia, telah diujikan buoy INAGOOS tahun 2007-2009 (Mbay \& Rahmania, 2010), namun masih mengalami kendala teknis dan non-teknis. Selanjutnya Kementerian Kelautan dan Perikanan (KKP) dalam hal ini P3TKP - Balitbang KP, mengembangkan buoy PLUTO (singkatan Perairan selaLU termoniTOr) tahun 2010 (Chandra, 2012). Generasi pertama buoy PLUTO ini memiliki spesifikasi sebagai berikut:

$\checkmark$ Sensor merek YSI 600R, dengan parameter suhu, salinitas, oksigen terlarut (DO) dan $\mathrm{pH}$.

$\checkmark$ Data logger (Non-Telemetri), untuk 1 tahun pencatatan.

$\checkmark$ Material alumunium (Non Marine specification).

$\checkmark$ Ukuran-ukuran buoy: 


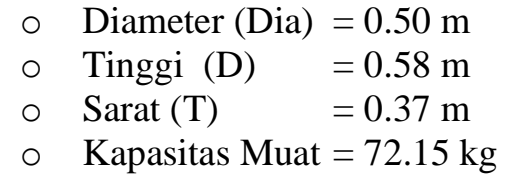

Buoy PLUTO ini diujikan pada perairan budidaya rumput laut di Wakatobi (Gambar 5).

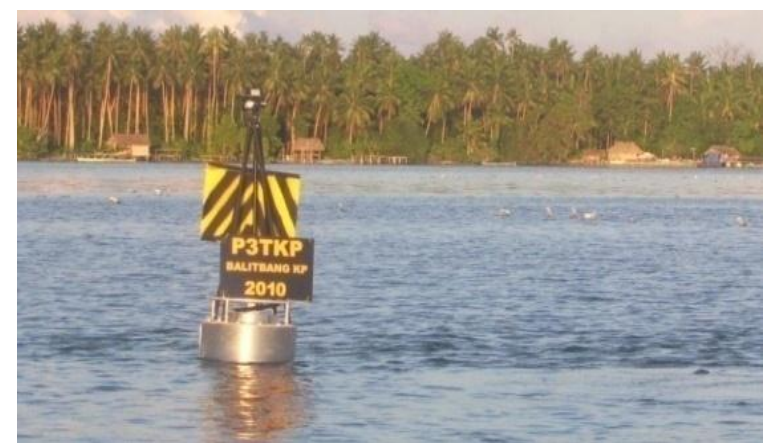

Gambar 5. Buoy PLUTO generasi pertama di Wakatobi Figure 5. First Generation of buoy PLUTO in Wakatobi Sumber: Chandra, 2012

Pada 2013, riset berjudul: Pengembangan Fasilitas Pemantauan Peringatan Dini Pencemaran, dikerjasamakan secara internal KKP dengan Direktorat PSDKP dan PIP - Ditjen PSDKP, berlokasi di UPT PSDKP di Pekalongan. Luaran dari kegiatan ini adalah sebuah perangkat keras (buoy) untuk memantau kualitas perairan di pelabuhan perikanan dan lingkungan perairan dimana ada kantor satuan kerja Ditjen PSDKP.

Paper ini membahas pengembangan buoy PLUTO sampai generasi kedua secara teknis dan manfaatnya secara ekologis, sebagai alat untuk peringatan dini pencemaran.

\section{BAHAN DAN METODE}

Bahan yang dipergunakan dalam kegiatan penelitian ini adalah satu (1) set buoy PLUTO, yang memiliki spesifikasi sebagai berikut:

1. Sensor suhu, salinitas, dan oksigen terlarut. Merek: Ponsel (Perancis).

2. Sitem telemetri, menggunakan sistem komunikasi data telepon GSM (GPRS). Dengan alamat server: 117.102.250.230

3. Dimensi buoy dengan tinggi $80 \mathrm{~cm}$ dan diameter $50 \mathrm{~cm}$, bila dibandingkan ukuran bolpen, dapat dilihat pada Gambar 6 .

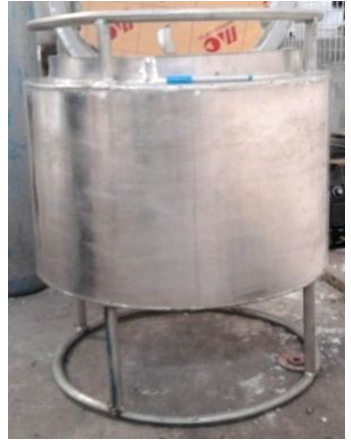

Gambar 6. Ukuran buoy dibandingkan bolpen

Figure 6. Buoy PLUTO's size be compared with ballpoint pen

Sumber: Dokumentasi pribadi

4. Displasmen (kapasitas muat $)=120 \mathrm{~kg}$.

5. Berat total buoy saja (light weight) $=38$ $\mathrm{kg}$.

Metodologi penelitian ini adalah sebagai berikut:

1. Buoy PLUTO diuji pendahuluan, dilokasi tambak milik UNIKAL (Universitas Pekalongan) (Chandra \& Kusumaningrum, 2013), seperti terlihat pada Gambar 7.

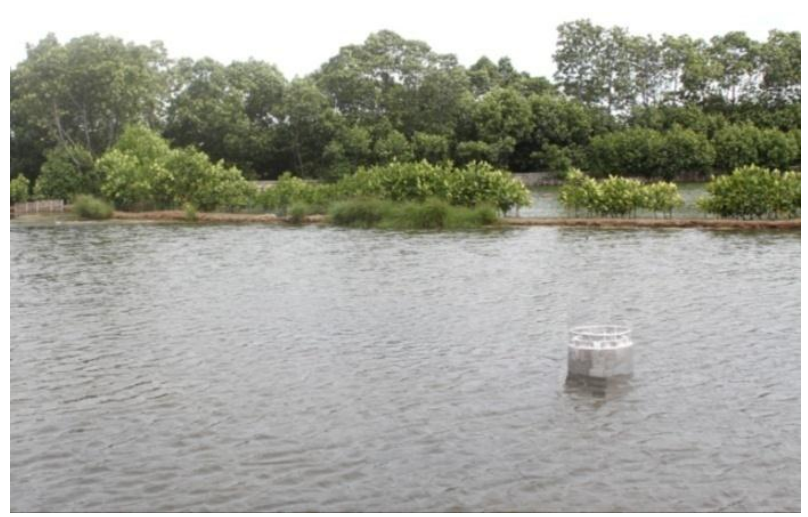

Gambar 7. Lokasi penempatan buoy PLUTO, ditambak UNIKAL

Figure 7. Buoy PLUTO deployment in UNIKAL's fish pond

Sumber: Dokumentasi pribadi

2. Setelah semua sistem berjalan baik, buoy PLUTO dibawa ke lokasi PPN Pekalongan untuk diujikan sebagai alat peringatan dini pencemaran (early warning for pollution).

3. Hasil pembacaan data pengukuran dibandingkan dengan pengukuran siklus pasang surut.

4. Pembahasan tentang hasil data yang diperoleh, serta peluang memanfaatkan alat ini sebagai alat peringatan dini (early 
warning) pencemaran di suatu kawasan perairan.

5. Kesimpulan.

\section{HASIL DAN PEMBAHASAN}

Sistem pemantauan perairan dengan memakai buoy PLUTO generasi kedua, yang bersifat telemetri. Menurut definisi dari Wikipedia, telemetri (sejenis dengan telematika) adalah sebuah teknologi yang membolehkan pengukuran jarak jauh dan pelaporan informasi kepada perancang atau operator sistem. Kata telemetri berasal dari akar bahasaYunani tele $=$ jarak jauh, dan metron $=$ pengukuran. Dengan menggunakan teknologi telemetri, kita dapat mengukur parameter perairan dan melihat hasilnya tanpa perlu berada dilokasi pengukuran. Teknologi ini memanfaatkan internet, sehingga dimanapun kita berada, asalkan ada internet, kita bisa melihat hasil pengukurannya (Gambar 8).

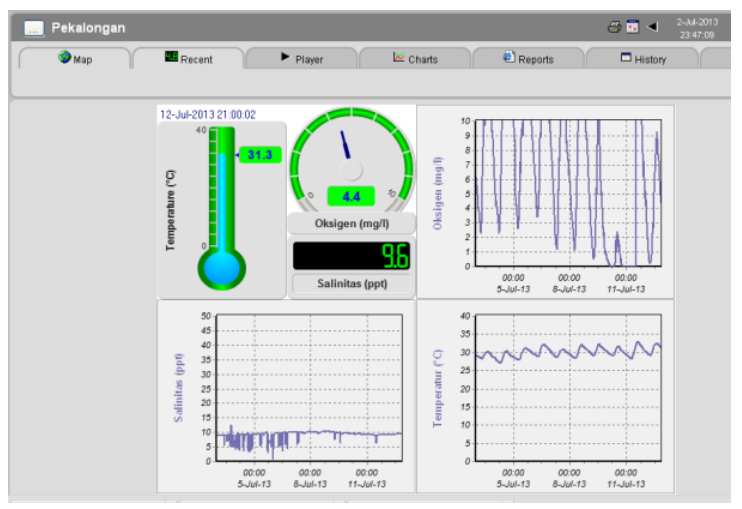

Gambar 8. Tampilan web dari buoy PLUTO di Pekalongan

Figure 8. The web dispay of PLUTO buoy in Pekalongan

Sumber: Dokumentasi pribadi

Waktu pengukuran dilakukan setiap 20 menit. Pengiriman data menggunakan paket GPRS milik Telkomsel. Biaya data per bulan Rp. 25.000,-. Pengisian ulang melalui anjungan tunai mandiri (ATM) adalah dengan memilih menu paket data, untuk nomor kartu GSM yang diletakkan di buoy PLUTO.

Skema kerja buoy pluto generasi kedua yang dilengkapi dengan sistem telemetri adalah sebagai berikut:

i. Sensor membaca kondisi perairan ii. Data dikirim melalui sinyal GSM (Telkomsel) ke BTS lalu ke satelit dan ke server

iii. Data tersimpan dan dapat dibaca pada server, baik melalui telepon seluler cerdas atau laptop.

iv. Analisa kondisi perairan oleh tim ahli berdasarkan data yang diterima, seperti terlihat pada Gambar 9.

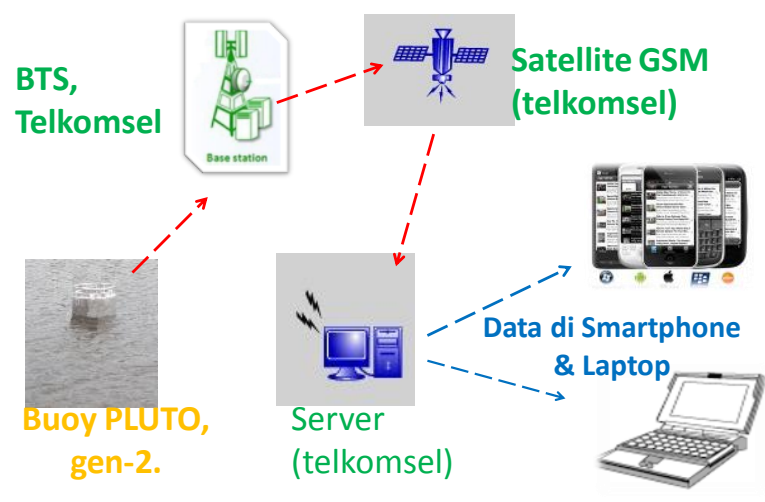

Gambar 9. Skema telemetri sistem buoy PLUTO

Figure 9. The telemetry system of PLUTO buoy Sumber: Dokumentasi pribadi

Kondisi saat ini kualitas perairan pesisir di seluruh dunia sedang mengalami penurunan (Cooley \& Doney, 2009; Guinotte \& Fabry, 2009; Rabalais, Turner, Diaz \& Justic, 2009; Sidabutar, 2012; Sea Technology, 2014). Salah satu indikasi penurunan kualitas perairan adalah kejadian marak alga (algal bloom). Fenomena marak alga (algal bloom) di perairan teluk Jakarta hampir setiap tahun terjadi dan telah mengakibatkan kematian massal (Sidabutar, 2012). Fenomena marak alga ini mengakibatkan defisiensi oksigen di dasar perairan (hipoksia) dan menyebabkan kematian biota dasar laut dan kematian ikan (Rabalais et al., 2009; Sidabutar, 2012; Sea Technology, 2014). Selain marak alga, kejadian pengasaman laut (ocean acidification) adalah indikasi lain turunnya kualitas perairan laut. Guinotte \& Fabry (2009) menyatakan bahwa sejak revolusi industri di Eropa, laut telah menjadi tiga puluh persen (30\%) lebih asam dan diprediksi menjadi $150 \%$ lebih asam pada akhir abad ini (abad 21). Pengaruh pengasaman laut dapat menurunkan pendapatan sektor perikanan dan membahayakan komunitas yang menggantungkan ekonomi dan budayanya 
terhadap sektor perikanan (Cooley \& Doney, 2009).

Kondisi perairan yang sudah tercemar, baik secara biologis maupun kimia, salah satunya ditandai dengan rendahnya kandungan oksigen terlarut (DO, dissolved oxygen) (Cheng, Hwang, Chen, Hou \& Hsieh, 2014; Howarth et al., 2000; Rabalais et al., 2009; Stramma et al., 2000). Kondisi ini sering disebut dengan kondisi hipoksik atau hipoksia (hypoxic/hypoxia, dimana kandungan

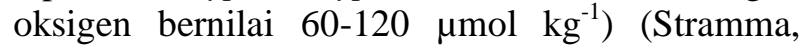
Schmidtko, Levin \& Johnson, 2000). Dalam banyak ekosistem perairan, hipoksia mengubah proses metabolisme, merubah kelimpahan, komposisi, diversitas, dan ukuran organisme. Kejadian hipoksia telah terjadi di teluk Meksiko, USA, tahun 2004 dan 2005 (Rabalais et al., 2009) (Gambar 10).
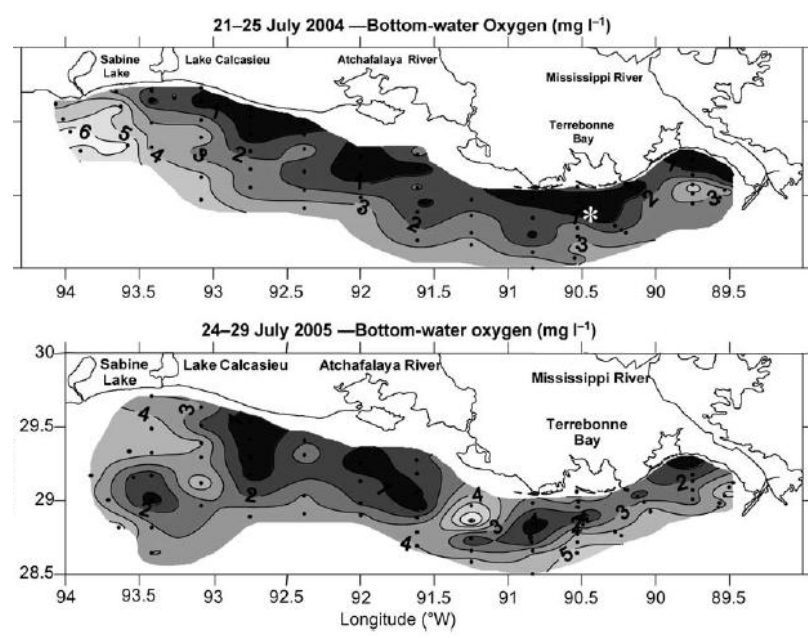

Gambar 10. Peristiwa Hipoksia di delta sungai Mississippi, teluk Meksiko, USA tahun 2004 dan 2005 Figure 10. Hypoxia at bottom layer of Mississippi Delta, Guf of Mexico, in 2004 and 2005 Sumber: Rabalais et al., 2009

Jika kondisi hipoksik ini terus turun dan mencapai nilai nol, maka dikategorikan kondisinya sudah anoksik (anoxic). Dari kondisi anoksik ini dapat meningkatkan produksi dan emisi gas $\mathrm{N}_{2} \mathrm{O}$ (dinitrogen oksida), yang merupakan sumber utama efek gas rumah kaca (greenhouse gas) (Strama et al., 2000; Sidabutar, 2012). Situasi anoksik ini diperkuat dengan aktifitas bakteri anaerob (tidak perlu oksigen) yang mengambil peranan dalam peruraian dan menghasilkan gas ke perairan seperti asam sulfida $\left(\mathrm{H}_{2} \mathrm{~S}\right)$ dan amoniak $\left(\mathrm{NH}_{3}\right)$ (Sidabutar, 2012). Akibatnya kematian massal biota perairan maupun di dasar perairan terjadi.

Pelabuhan perikanan di Indonesia umumnya bersinggungan dengan wilayah ekosistem pantai dan terumbu karang (Indonesian FP, 2009). Dapat dilihat pada Gambar 11, lokasi pelabuhan perikanan yang di kelola Direktorat Jenderal Perikanan Tangkap (DJPT, KKP) di bagian barat Indonesia. PPN Pekalongan berada di laut Jawa, berlokasi di propinsi Jawa Tengah, dan berada pada wilayah pengelolaan perikanan 712 .

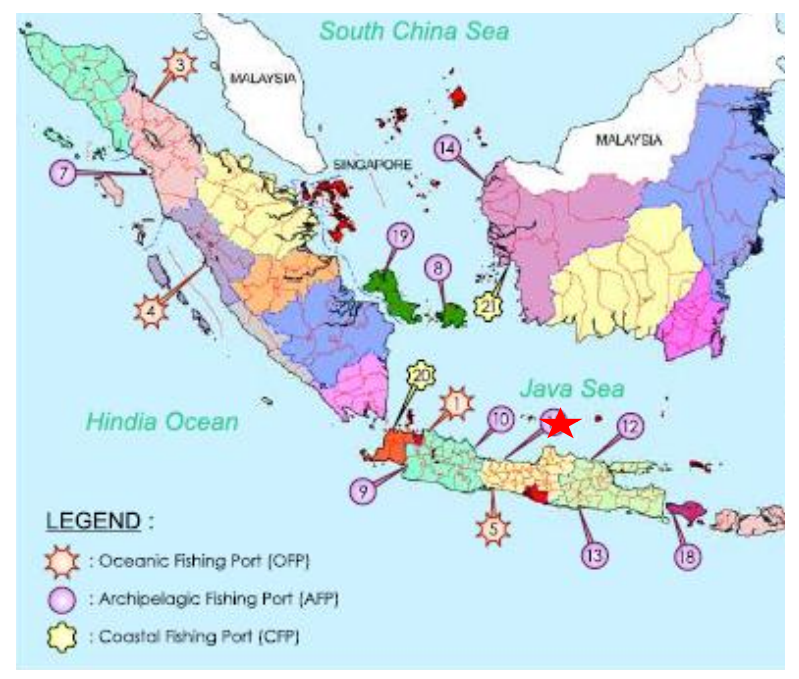

Gambar 11. Lokasi pelabuhan perikanan yang dikelola DJPT - KKP dan lokasi PPN Pekalongan bertanda bintang merah

Figure 11. The Fishing port location under management of Directorate General of Capture Fishery, MMAF and PPN Pekalongan noted by red coloured star Sumber: Indonesian FP, 2009

Pencemaran di kolam pelabuhan perikanan terjadi karena aktifitas manusia. Contoh sumber pencemar: limbah ikan olahan, sisa oli dan bahan bakar minyak (BBM) kapal ikan, sabun, deterjen dan cat dari galangan kapal.

Lokasi uji implementasi pemantauan kualitas kolam pelabuhan adalah di pelabuhan perikanan nusantara (PPN) Pekalongan (Gambar 12). Lokasi ini diduga sudah tercemar berat oleh limbah batik, oli, minyak, sampah kapal ikan, sampah galangan dan dari TPI (tempat pelelangan ikan). Pengamatan visual secara langsung terlihat perairan tidak berwarna biru, melainkan berwarna cokelat kehitaman. 


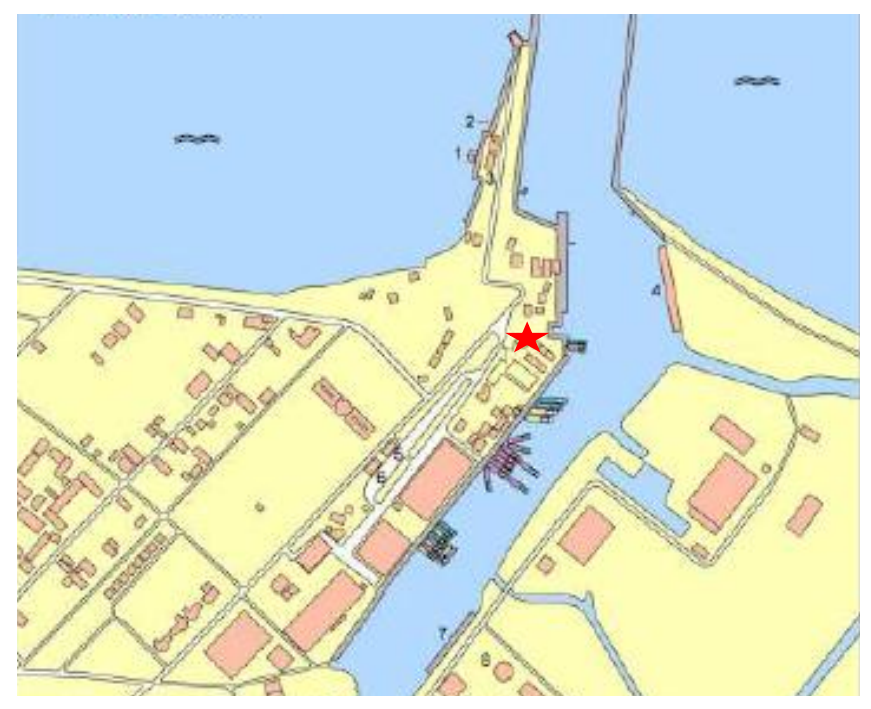

Gambar 12. Denah PPN Pekalongan, dan lokasi uji (bintang warna merah) pemantauan kualitas air secara online

Figure 12. Layout of archipelagic fishing port of Pekalongan,

and testing location (Red coloured star) of online water quality monitoring

Sumber: Indonesian FP, 2009

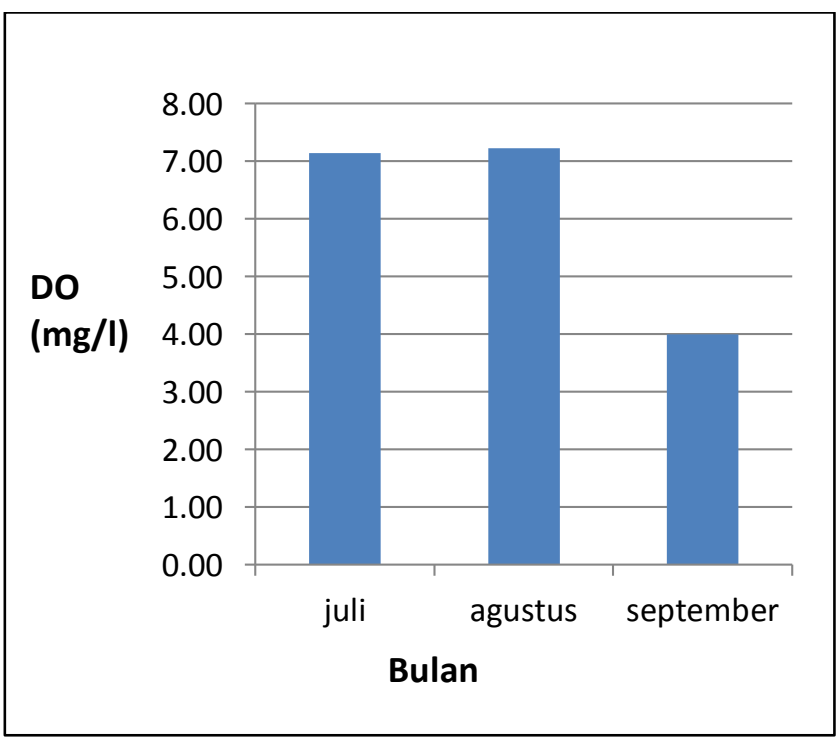

Gambar 13. Nilai rata-rata bulanan DO hasil perekaman Buoy PLUTO di tambak Universitas Pekalongan

Figure 13. Monthly average of DO, recorded by PLUTO buoy in UNIKAL's pond

Sumber: Chandra \& Kusumaningrum, 2013

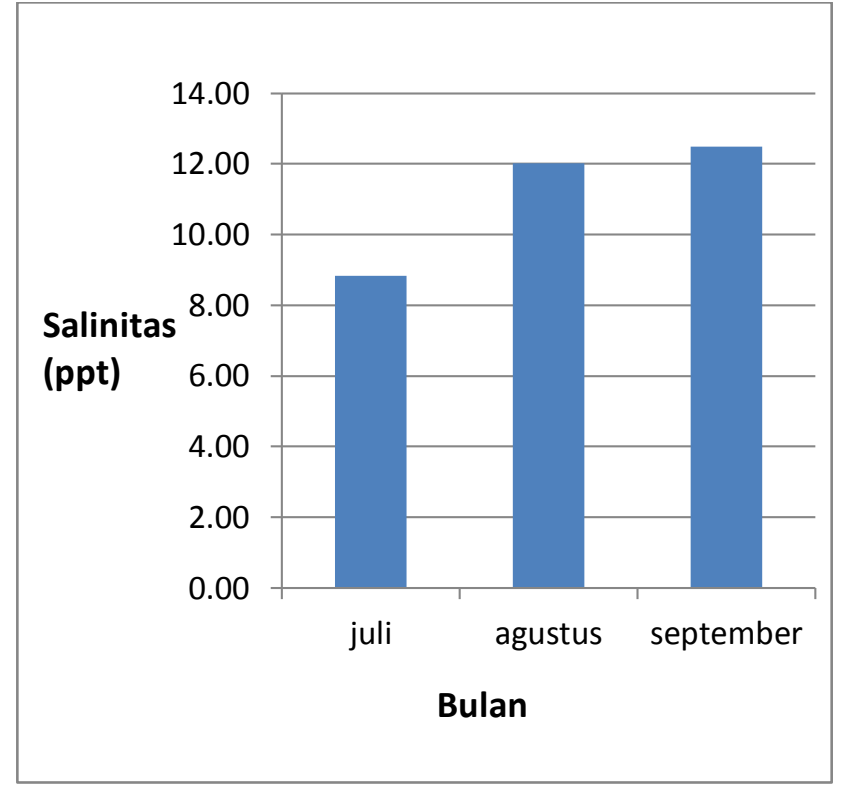

Gambar 14. Nilai rata-rata bulanan salinitas hasil perekaman Buoy PLUTO di tambak Universitas Pekalongan

Figure 14. Monthly average of salinity, recorded by PLUTO buoy in UNIKAL's pond

Sumber: Chandra \& Kusumaningrum, 2013

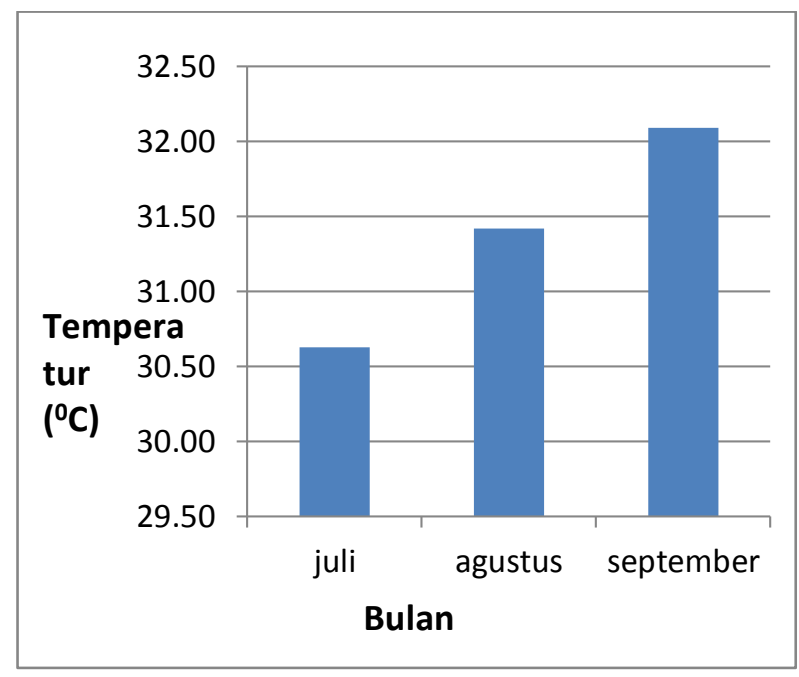

Gambar 15. Nilai rata-rata bulanan temperatur hasil perekaman Buoy PLUTO di tambak Universitas Pekalongan

Figure 15. Monthly average of temperature, recorded by PLUTO buoy in UNIKAL's pond

Sumber: Chandra \& Kusumaningrum, 2013 
Uji pendahuluan dilakukan di tambak milik Universitas Pekalongan berjalan dengan baik (Chandra \& Kusumaningrum, 2013). Hasil pengukuran kualitas perairan tambak menunjukkan alat buoy PLUTO dapat bekerja dengan baik dan sistem informasinya lancar. Hasil pengukuran tiga (3) parameter: DO, salinitas dan temperatur ratarata per bulan dapat dilihat pada Gambar 13-15.

Pengujian alat pemantau perairan buoy PLUTO di tambak bertujuan untuk mengumpulkan data dasar dari perairan yang relatif tidak tercemar, karena masih digunakan untuk budidaya ikan bandeng dan mujair. Kandungan DO di tambak menunjukkan

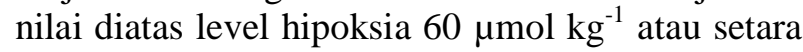
dengan $1,920 \mathrm{mg} / \mathrm{L}(60 \times$ [ 16 (massa relative atom) x 2 (atom)]) (Stramma et al., 2000). Ini menjadi tanda/sinyal bahwa ekosistem tambak masih baik, dimana fitoplankton masih melakukan fotosintesa dan konsumsi oksigen masih seimbang.

Simanjuntak (2009) menyatakan bahwa perubahan kondisi massa air dalam suatu perairan dapat diketahui dengan melihat karakteristiknya yang meliputi oksigen terlarut (DO) dan kandungan zat hara (fosfat $\left.\left(\mathrm{PO}_{4}\right)\right)$, nitrat $\left(\mathrm{NO}_{3}\right)$, dan silikat $\left(\mathrm{SiO}_{2}\right)$. Simanjuntak (2012) memberikan kesimpulan hasil penelitiannya bahwa nilai DO akan semakin rendah pada perairan dekat pantai, sedangkan kadar tinggi ditemukan dilokasi yang jauh dari pantai. Cheng et al. (2012) juga memakai indikator DO dalam penelitian kualitas air di muara dan perairan pesisir. Karena sensor yang sesuai dan ada di buoy PLUTO adalah DO, maka parameter tersebut akan dipakai sebagai petunjuk awal pencemaran, atau ketidakseimbangan kualitas perairan.

Pencemaran air adalah masuknya atau dimasukkannya makhluk hidup, zat, energi dan atau komponen lain kedalam air oleh kegiatan manusia, sehingga kualitas air turun sampai tingkat tertentu yang menyebabkan air tidak dapat berfungsi sesuai dengan peruntukannya (PP no. 82, 2001). Pencemaran perairan yang terjadi di PPN Pekalongan secara visual dan dari informasi verbal bisa dilihat secara jelas dan dimengerti asal sumbernya. Sumbernya antara lain: minyak dan oli dari kapal ikan, sisa pembersihan ikan dari TPI, cat dari galangan dan kapal ikan, sisa makanan dari kapal dan warung.
Lokasi penempatan buoy PLUTO di kolam PPN Pekalongan dapat dilihat pada Gambar 12. Hasil pengukuran kondisi perairan dapat dilihat pada Gambar 16a, 16b, 20 dan 21. Pada gambar tersebut terlihat dengan jelas, sejak 10-16 Oktober 2013, nilai kandungan oksigen (DO) naik hanya pada sekitar jam 12 sampai dengan 18 WIB. Selebihnya nilai DO adalah nol (0), atau kondisinya anoksik.

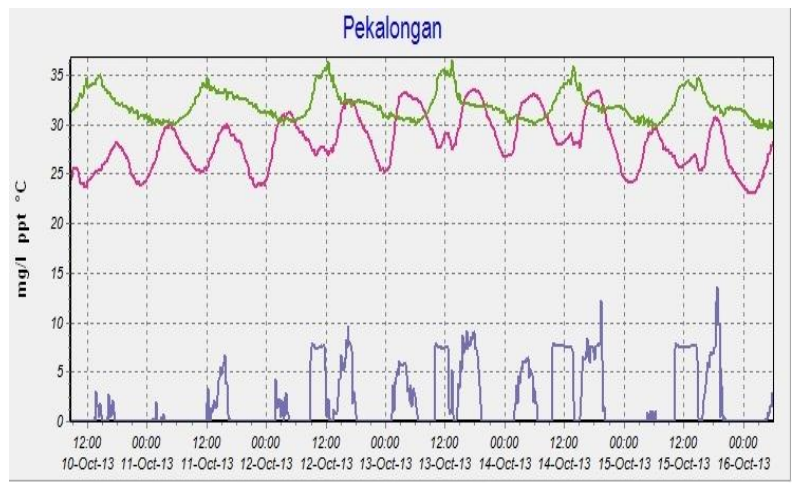

Gambar 16a. Parameter DO (warna biru), parameter salinitas (warna jingga), parameter suhu (warna hijau) dari telemetri buoy PLUTO

Figure 16a. DO parameter (blue color), Salinity parameter (violet color), temperature parameter (green color) from buoy PLUTO's telemetry Sumber: Hasil pengukuran

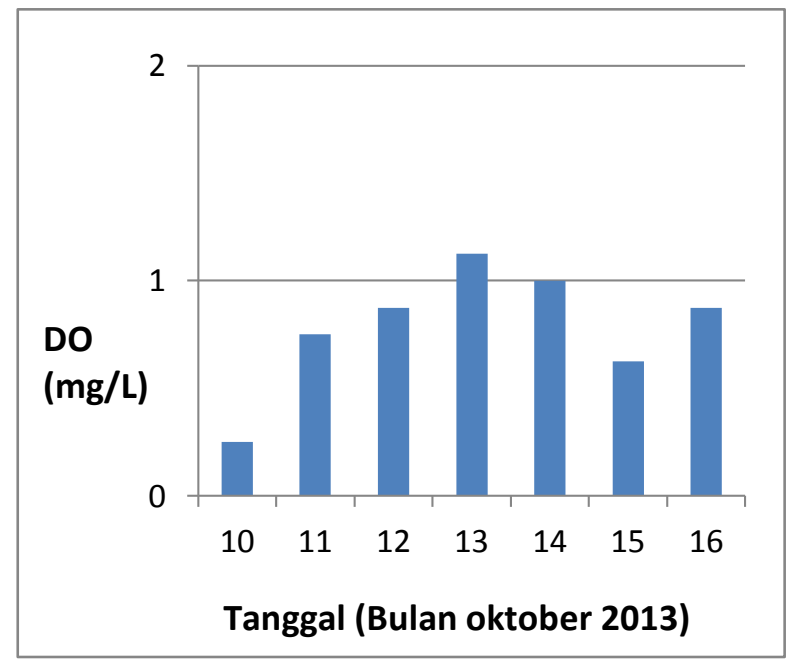

Gambar 16b. Nilai harian rata-rata parameter DO Figure 16b. Daily average value of $D O$ Sumber: Hasil pengukuran

Menurut Simanjuntak (2009), Howarth et al. (2000), Stamma et al. (2000), Rabalais et al. (2009) dan Cheng et al. (2012), pantai dan perairan pesisir yang tercemar ditandai dengan rendahnya 
kandungan oksigen (DO) dibandingkan dengan rata-rata perairan terbuka.

Kenaikan nilai DO sekitar jam 12-18 WIB diduga karena terjadinya proses pasang air laut. Untuk mengujinya, data prediksi pasang surut dari BAKOSURTANAL pada Oktober 2013, dipergunakan sebagai referensi, dengan posisi pengukuran di kota Semarang. Data Oktober 2013 tersebut kemudian diamati khususnya pada jam 11-12 kemudian 18-19 waktu Semarang (Gambar 17).

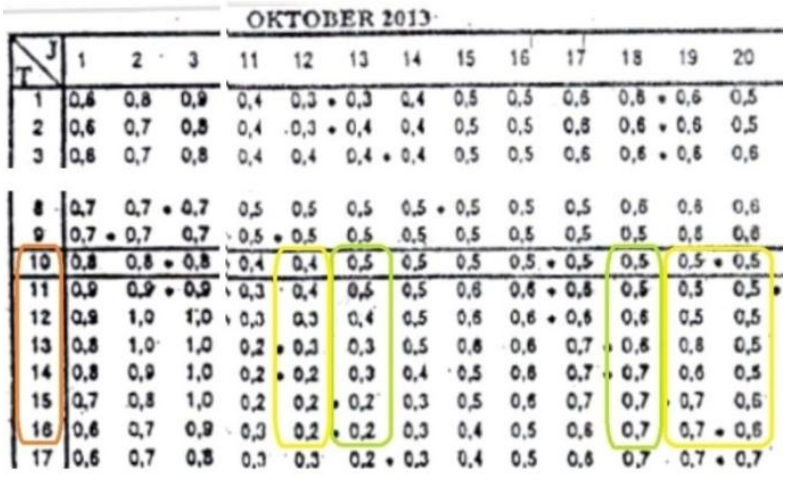

Gambar 17. Prediksi pasang surut dari Perangkat BAKOSURTANAL untuk Oktober 2013

Figure 17. Table for tidal prediction from Bakosurtanal in October 2013

Sumber: Bakosurtanal, 2013

Berdasarkan Gambar 17, terlihat pada jam 11-12 siang (data dalam lingkaran warna hijau dan kuning) mulai terjadi pasang laut di Semarang dan mulai jam 18-19 terjadi surut. Pada 10 Oktober 2013jam 12 tinggi pasang air 0,4m (dari duduk tengah) kemudian jam 13 menjadi 0,5m. Pada 11 Oktober 2013 jam 12 tinggi pasang air 0,4 mkemudianjam 13 menjadi $0,5 \mathrm{~m}$. Pada 12 Oktober 2013 jam 12 tinggi pasang air 0,3m kemudian jam 13 menjadi $0,4 \mathrm{~m}$; demikian seterusnya. Karena posisi kota Pekalongan dan Semarang yang sama-sama di pantai utara Jawa Tengah, maka data prediksi BAKOSURTANAL yang di Semarang dipakai sebagai referensi. Hal ini diperkuat dengan data salinitas (Gambar 13, warna jingga) yang juga naik seiring kenaikan grafik DO (Gambar 16a, warna biru).

Pada 14 Oktober 2013, jam 19 tinggi pasang air 0,6m (dari duduk tengah) kemudian jam 20 menjadi $0,5 \mathrm{~m}$ (mulai surut). Tanggal 15 Oktober 2013, jam 19 tinggi pasang air $0,7 \mathrm{~m}$ kemudian jam
20 menjadi 0,6m. Tanggal 16 Oktober 2013 jam 19 tinggi pasang air $0,7 \mathrm{~m}$ kemudian jam 20 menjadi $0,6 \mathrm{~m}$.

Kenaikan nilai DO juga dibuktikan oleh Rabalais et al. (2009), ketika terjadi badai tropis Bill di Louisiana, USA pada Juni 2003. Kondisi hipoksik di pantai Luisiana mendadak berubah nilai DO-nya menjadi tinggi, karena masuknya air dari laut lepas ke perairan pesisir. Dari angka $0,2 \mathrm{mg} / \mathrm{L}$ kandungan oksigen terlarut menjadi diatas $3 \mathrm{mg} / \mathrm{L}$. Setelah badai tropis Bill berlalu, nilai DO kembali ke level 0,2mg/L (Gambar 18).

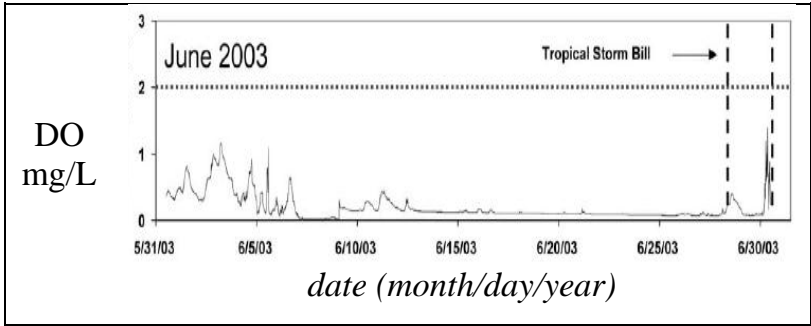

Gambar 18. Kenaikan DO saat terjadi badai tropis Bill, Juni 2003, menjadi diatas hipoksia

Figure 18. The DO Increasing value when Bill tropical storm happenned on June 2003, over the hypoxic level Sumber: Rabalais et al., 2009

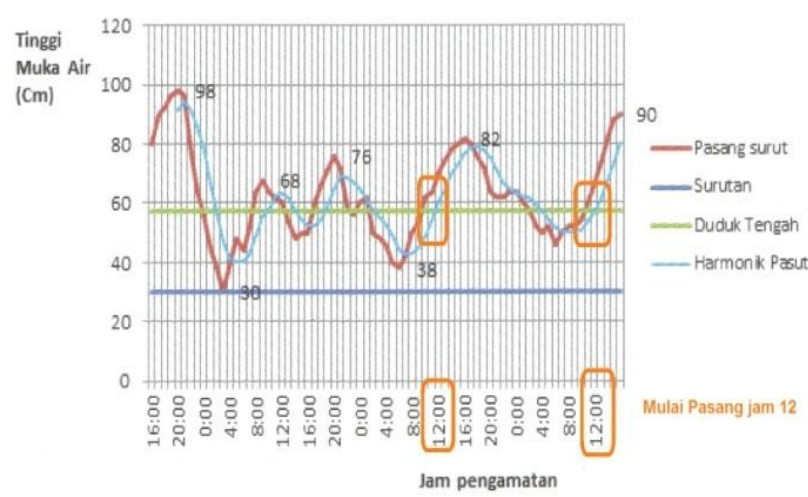

Gambar 19. Grafik pasut di Pekalongan, 18-21 April 2011

Figure 19. Tidal graph in Pekalongan, 18-21 April, 2011

Sumber: Prihatno, 2012

Prihatno (2012) melakukan studi pasang surut di Pekalongan pada 2011. Ciri-ciri kontur pantai Pekalongan adalah landai. Pada jarak $1 \mathrm{~km}$ dari garis pantai memiliki kedalaman laut $5 \mathrm{~m}$, sehingga rerata kemiringan dasar laut adalah 0,005 (5:1000). Kedalaman laut yang dekat pantai adalah $20 \mathrm{~m}$. Hasil pengukuran pasut pada 8-11 April 2011 
menunjukkan waktu pasang dari dudukan tengah (MSL) adalah sekitar jam 12, seperti pada Gambar 19.

Kota Pekalongan, Jawa Tengah, seperti juga kota pesisir pantai utara pulau Jawa, seperti Semarang, Surabaya, dan Jakarta sering mengalami banjir rob, yang disebabkan air pasang dan gelombang laut (Prihatno, 2012). Jadi, dugaan naiknya nilai DO di muara PPN Pekalongan terbukti, dengan memperhatikan bahwa sekitar jam 12 sampai jam 18 terjadi pasang di Pekalongan. Yang mana hal ini mirip dengan yang terjadi di Semarang, berdasarkan data dari BAKOSURTANAL (2013) dan kajian Prihatno (2012).

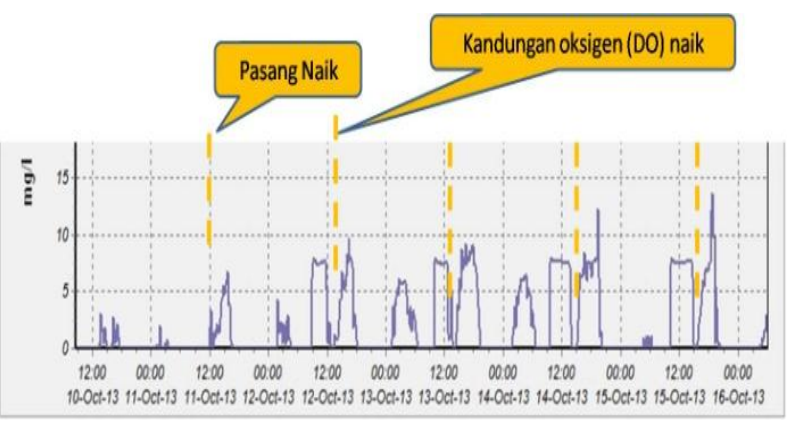

Gambar 20. Penjelasan grafis kenaikan nilai DO (mg/L) dan proses pasang naik air laut

Figure 20. Graphics explanation of DO $(\mathrm{mg} / \mathrm{L})$ rising number and its relation due to high tide process Sumber: Hasil pengukuran

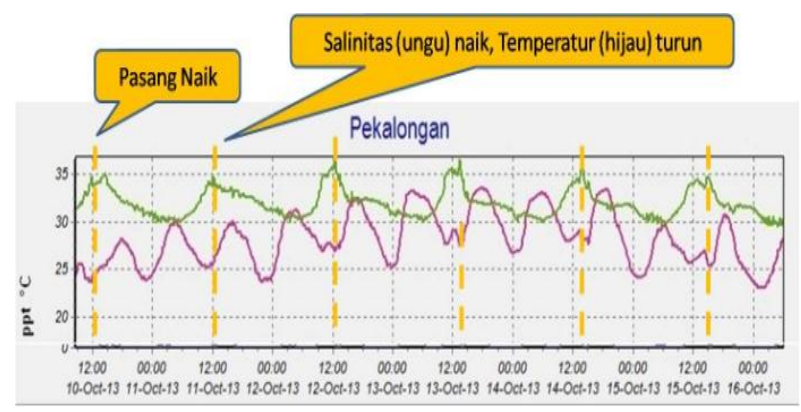

Gambar 21. Penjelasan grafis kenaikan nilai salinitas (dalam satuan ppt) dan turunnya suhu (celcius) dikaitkan proses pasang naik air laut

Figure 21. Graphics explanation of salinity (ppt) rising number and temperature (celcius) decreasing number and its relation due to high tide process Sumber: Hasil pengukuran

Berdasarkan hasil dan uraian diatas (seperti dijelaskan pada Gambar 20 dan 21),terlihat dan teruji bahwa sistem pemantauan kualitas perairan secara telemetri dengan memakai buoy PLUTO berjalan dengan baik. Alat ini dapat dijadikan sebagai suatu sistem peringatan dini (Early Warning) untuk pencemaran di perairan pesisir, danau, waduk dan tambak. Parameter yang bisa dijadikan acuan adalah oksigen terlarut (DO) dan salinitas.

\section{KESIMPULAN DAN SARAN}

Uji implementasi buoy PLUTO di PPN Pekalongan telah dilakukan. Hasilnya menunjukkan sistem telemetri bekerja dengan baik dan data dapat diperoleh dengan mudah. Dari hasil pengukuran dengan menggunakan parameter DO dan salinitas menunjukkan bahwa nilai DO dan salinitas berubah seiring dengan terjadinya proses pasang surut perairan Pekalongan.

Terkait nilai DO yang berada pada level anoksik, pencemaran dan limbah yang masuk ke kolam pelabuhan adalah sumber utama turunnya kualitas perairan di kolam pelabuhan. Pemeliharaan kualitas perairan kolam hanya dapat dilakukan dengan tidak membuang limbah dan polutan ke kolam pelabuhan.

Uji pemantauan kualitas perairan secara telemetri berhasil dengan menggunakan alat buoy PLUTO. Alat ini selain untuk pemantauan, dapat juga digunakan untuk peringatan dini terjadinya pencemaran, dengan memakai tiga (3) sensor yaitu suhu, salinitas, dan oksigen terlarut (DO). Penelitian dan perekayasaan alat ini adalah yang pertama kali dilakukan di Indonesia, dan berhasil dengan baik.

Saran yang dapat diberikan adalah alat ini agar dibuat lebih kecil dari segi ukuran agar mudah penanganannya.

\section{UCAPAN TERIMA KASIH}

Kegiatan ini berlangsung dengan dukungan dari pihak PSDKP - KKP, P3TKP - Balitbang KP dan Universitas Pekalongan. Banyak terima kasih buat Bapak Nugroho Aji, Suharta, Didik, Andrik, Kukuh, Ibu Hetty dari PSDKP. Bapak Ngurah W., Anwar, Ari, Ibu Bertha dan Yusti, dari P3TKP. Bapak Hadi P., dan pak Bulus dari Universitas Pekalongan. 


\section{DAFTAR PUSTAKA}

BAKOSURTANAL. (2013). Prediksi pasang surut. Semarang.

Chandra, H. (2012). Perekayasaan buoy PLUTO untuk memantau kualitas perairan budidaya rumput laut di kabupaten Wakatobi, Sulawesi Tenggara, Jurnal Kelautan Nasional, 7(3), 166-174.

Chandra, H \& Kusumaningrum, PD. (2013). Data kualitas perairan tambak di Pekalongan, hasil instalasi buoy PLUTO. Prosiding Seminar Naisonal Perikanan Indonesia, 21-22. Jakarta: Sekolah Tinggi Perikanan.

Cheng, S., Hwang, G., Chen, C., Hou, W., Hsieh, H. (2012). An Integrated modelling approach to evaluate the performance of an oxygen enhancement device in the Hwajiang wetland, Taiwan. Journal of Ecological Engineering, 42, 244-248.

Cooley, SR \& Doney, SC. (2009). Ocean Acidification's Impact on Fisheries and Societies: A U.S. Perspective. Current, The Journal of Marine Education, 25(1), 15-19.

Detrick, R., Frye, D., Collins, J., Gobat, M., Grosenbaugh, M.,...Horton, E. (2000). DEOS moored buoy observatory design study. Arlington USA: The National Science Foundation/Ocean Sciences Division.

Gates, P., Cusack, P., Watt, P. (1996). South Pacific Commision Fish Aggregating Device (FAD) Manual. (Vol. 2), Rigging Deep-water FAD Moorings. Noumea New Caledonia: South Pacific Commission.

Guinotte, J. \& Fabry, VJ. (2009). The threat of acidification to ocean ecosystems. Current, The Journal of Marine Education, 25(1), 2-7.

Holappa, K. (2001). Micro-buoys for the characterization of the air-sea interface. Final Report, Ocean Sensor Systems, Inc. Florida, USA: Ocean Sensor Systems.

Howarth, R., Anderson, D., Cloem, J., Elfring, C., Hopkinson, C.,...Walker, D. (2000). Nutrient pollution of coastal rivers, bays, and seas. Issues in Ecology, (No. 7). Washington DC, USA: Ecological Society of America.

Howe, G. (2014). Developing a buoy-based offshore wind resource assesment system. Sea Technology Magazine February 2014, 41-43.

http://www.oceanor.info/news/index.htm

http://www.spiegel.de/fotostrecke/photo-gallerytsunamis-devastate-indonesia-fotostrecke61063.html

https://www.flickr.com/photos/civilbeat/8197795999/ Indonesian Fishing Ports. (2009). Directorate General of Capture Fisheries (DGCF), Ministry of Marine Affairs and Fisheries (MMAF), and
Japan International Cooperation Agency (JICA)

Mbay, L. O. N., \& Rahmania, R. (2010). Pembuatan buoy pantai untuk mendukung kegiatan perikanan budidaya di Kepulauan Seribu. Jurnal Kelautan Nasional, 5(3), 175-187.

Mullen, K. \& Whelan, JR. (2013). Control buoys, operability and reliability perceptions. Presentation INTECSEA, WorleyParsons Group.

Pandoe, W dan Djamaluddin, R. (2009). The Indonesian tsunami buoy development program. Prosiding Seminar ISOI, 284-295. Jakarta: Ikatan Sarjana Oseanografi Indonesia.

PP No. 82 tahun (2001). Tentang: Pengelolaan Kualitas Air dan Pengendalian Pencemaran Air.

Prihatno, H. (2012). Variasi kenaikan muka laut di wilayah pesisir Pekalongan, dari analisis pasang surut dan angin. Jurnal Segara, 8(1), 27-34. Jakarta: Pusat Penelitian dan Pengembangan Sumberdaya Laut dan Pesisir.

Rabalais, NN., Turner, RE., Diaz, RJ., Justic, D. (2009). Global change and eutrophication of coastal waters. ICES Journal of Marine Science, 66, $1528-1537$.

Sea Technology. (2014). US House Passes Reauthorization of Act To Control Algal Blooms, Hypoxia. Sea Technology Magazine July 2014, 51 .

Sidabutar, T. (2012). Kajian Eutrofikasi Dan "Harmful Algal Blooms" Di Perairan Teluk Jakarta. Prosiding Seminar Nasional Perikanan Indonesia 13-14 November 2012, 481-490. Jakarta: Sekolah Tinggi Perikanan.

Simanjuntak, M. (2009). Kandungan zat hara di perairan Teluk Jakarta.Prosiding PIT-VI ISOI, 302-315, Jakarta: Ikatan Sarjana Oseanografi Indonesia.

Simanjuntak, M. (2012). Pengaruh suhu dan salinitas terhadap oksigen terlarut kaitannya dengan biota laut di perairan Lamalera, Nusa Tenggara Timur.Prosiding Seminar Nasional Perikanan Indonesia 13-14 November 2012, 221-232. Jakarta: Sekolah Tinggi Perikanan.

Stramma, L., Schmidtko, S., Levin, LA., Johnson, GC. (2010). Ocean oxygen minima expansions and their biological impacts. Deep Sea Research PartI, 587-595. doi: 10.1016/j.dsr.2010.01.005

Wikipedia. http://id.wikipedia.org/ 